\title{
Security-Development Nexus: China's Policy Framework towards Africa
}

\author{
Dr Bertha Z. Osei-Hwedie and Napoleon Kurantin*
}

\begin{abstract}
The article analyzes China's foreign policy approach in Africa in the post-Cold War era using the security-development nexus. China's version of security-development nexus is labelled as economic peace as it is derived from the premise that economic deprivation causes insecurity. Its nexus is based on the domestic experience of promoting planned development to tackle poverty to foster peace and security. Such experience is what China seeks to export to the African continent. Therefore, the nexus in Africa is targeted at tackling development problems to ameliorate poverty, and domestic insecurity caused by a combination of poverty and institutional incapability. Economic problems and political instability threaten both human and state security in Africa, making the continent the poorest region and one of the most unstable region in the world. The nexus indicates that security and development are intricately intertwined. The nexus is articulated through the Forum on China Africa Cooperation. However, the rapid and increased involvement of China in Africa's security and development, and increased violence against Chinese businesses and citizens, have generated heated debate between the pessimists and optimist about its role, while paying little attention to the position of Africa on the securitydevelopment nexus.
\end{abstract}

KEY WORDS: Africa, China, security-development nexus, China African Policy, FOCAC, BRI.

* Dr Bertha Z. Osei-Hwedie and Napoleon Kurantin: Prof. Bertha Z. Osei-Hwedie and Napoleon Kurantin are with Ghana Institute of Management and Public Administration, School of Public Service and Governance, Accra, Ghana. 


\section{Security-Development Nexus: China's Policy Framework towards Africa}

\section{Introduction}

The increasing presence of China in international geo-politics has impacted greatly on Africa's strive for sustainable security and economic development. China's relationship with Africa has contributed to the promotion of development and security on the continent. However, the partnership has changed overtime. It has evolved from support for anti-colonial struggles of the 1950s; nurturing the South-South cooperation; to boosting economic and security ties. In the post-War era, China's foreign policy towards Africa is geared towards efforts in capacitybuilding for maintaining and strengthening peace, security and development. Most African leaders have welcomed the current China's rapid engagement in Africa's economy, peace and security as a means to promote economic growth, boost its bargaining power in the international arena, especially, with Western powers, and enhance Africa's voice in international forums. On its part, China hopes to retain and enhance its power position and influence in Africa and the world as a whole; achieve its economic and security interests in Africa; and contribute to international peace and security. This would be reminiscent of mutuality of interests in a win-win fashion. However, the partnership has been subjected to scrutiny and questions have been raised, both within Africa and outside the continent. The article, therefore, contributes to the on-going debate on the role of China's security and development activities to answer questions of whose security and whose development; and to understand Africa's position in its partnership with China.

The article is divided into four main sections: First, is the discussion of the security-development nexus conceptualization in general, highlighting its origin and elements. Second, the Chinese version of security-development nexus, and the channels through which the nexus is articulated, and how it has shaped relations with Africa, are examined. Third, the importance of Chinese security-development nexus to Africa's development and security is discussed. Fourth, China's security and strategic interests and roles in Africa are explained within the context of its model of security-development nexus. Lastly, the focus is on debates or controversies associated with its role in Africa, and Africa's stance on Chinese engagement on the continent. 


\section{Security-Development Nexus: An Overview}

The security-development nexus has become the basis of national and global policy-making, especially, of donors. It is employed by think-tanks to solve problems and challenges in the twenty-first century (Stern \& Ojendal, 2010; Bisca, 2018). The development-security nexus originated after World War Two, as a framework for development aid by Western donors to developing countries (Barrett, 2018; Koponen, 2010). The nexus was aimed at ensuring security for Western countries by embarking on global development against poverty in the developing world as poverty was viewed as a threat to both security in the West and developing countries. It was also designed to prevent developing countries from aligning with Communists in Eastern Europe or China. However, the nexus became an imperative since 1990s, and more, especially, after September 11, 2001 as a framework for intervention by donors. The nexus became the cornerstone of a coherent, comprehensive and multilateral policy for Western Organization for Economic Cooperation and Development-Development Assistance Committee (OECD-DAC) donors and defined their common security and development policies in the recipient countries worldwide, particularly, post-conflict and fragile ones.

The security-development nexus, though a contested conceptualization, has replaced the previous separation of security and development into two distinct disciplines. According to Chandler (2007), before the security and development nexus paradigm entered the research field, security and development were viewed as two separate sectors with different ideas and aims. There are two reasons behind the change of paradigm. First, the shift is rooted in the belief that the merging of security and development will create the most coherent and well managed policies with regards to assistance extended to post-conflict countries, or failed and weak states (Chandler, 2007). Second, there is a belief that long-term development requires, and hinges upon security; and that lasting security depends upon development (International Peace Academy, 2004, p.1). This view is reinforced by Bisca's (2018) explanation of security-development nexus as consisting of development interventions that shape security outcomes which in turn determine development outcomes.

The concepts of security and development have evolved, overtime. Traditionally, security focused on the state in terms of the military and external threats. However, later, the emphasis has also been on the threat of conflict and armed violence to human security. Hence, the 
reconceptualization of security by the United Nations Human Development Programme (UNDP) Report (1994) as freedom from fear and want by an individual. The new concept of human security by the UNDP Report (1994), takes note of the widened, multi-dimensional view of security, with seven elements: economic, health, food, environmental, personal, community, and political security (Anderson, 2012). Accordingly, the new paradigms of security studies include environmental decline, natural disasters, poverty, deadly diseases and resource scarcity as security threats, not only to the state itself, but to humans and international community (Anderson, 2012). Thus, the emphasis on traditional national security has not lost importance, but made equally important to international and global security due to the recognition that the world today is interdependent politically, socially and economically (Baldwin, 1997). However, it is assumed that attainment of human security guarantees state security.

Similarly, the meaning of development has changed overtime: fundamentally, from mostly being linked with economy and industrialization in the 1940s (Johansson, 2014), to economic growth and modernization in the 1960s, to include economic growth and structural adjustment change, since the 1980s (Sumner \& Tribe, 2008), to democratization, good governance and welfare, since the 1990s. Development, thus, entails transformation of society and advancement of democracy and good governance as the means for fostering poverty reduction as stipulated in the Millennium Development Goals (MDGs) and Sustainable Development Goals (SDGs). Hence, the focus on human development, as a shift from state-centric development (Pietersee, 2000). The West believes that poverty in countries, with very low Gross National Product (GNP), and state fragility or weakness cause conflict and armed violence hence the need for securitization of development that intertwines the two concepts such that there can be no security without development, and no development without security (Koponen, 2010, p. 40). This has necessitated the transformation and widening of the security-development nexus from mere humanitarian intervention in the 1990 s to conflict resolution and post-war reconstruction to reduce or eliminate armed conflict and stop its recurrence; and promotion of good governance with respect for human rights reflected in the Responsibility to Protect principle. Good governance translates into "human-rights-based development" that allows for simultaneous promotion of security elements (Koponen, 2010, pp. 33-34). 
The nexus has been the basis for Western donor and multilateral institutions' aid intervention in developing countries, primarily, those which are weak, fragile, incapable, and facing development problems, and security threats. Threats from fragile developing countries, including civil wars, refugees, terrorism, violence, and poverty, among other factors, are viewed by the West as posing insecurities for Europe and the United States of America. These explain the reason why western donors, including the United Kingdom Department for International Development (DFID), and the United Nations (UN), initiated and argued that "development and security are inextricably linked" (Stern \& Ojendal, 2010, pp. 5, 22 ) such that one cannot exist without the other. This is akin to the narrative that there is no development without security and vice versa. Hence the need for security-oriented development policy that securitizes development policy and development-oriented security policy that has a broadened and 'developmentalized' definition of security as provided by the UNDP (1994). The nexus would result in the achievement of peace, development and security to allow for human freedom and dignity.

\section{China's Security-Development Nexus}

The West is not the only donor that employs the security-development nexus as the basis of its foreign policy towards Africa. Emerging powers have also embraced the nexus in their foreign policy, primarily, China, with its own version of the security-development nexus. China's security-development nexus is an alternative to the Western conceptualization of securitydevelopment nexus. Whereas the Western security-development nexus is informed by the idea of liberal peace as the basis for intervention in developing countries, China's nexus is the economic peace with emphasis on "national sovereignty, political stability and state-directed, infrastructure-led economic development" (Hameiri, Jones \& Zou, 2019, pp. 473-474). Therefore, its nexus is relatively new to that of the West. It has gathered momentum and significance, and embraced by most African leaders.

The security-development nexus means that China has shifted its focus from military-security policy, which fostered security cooperation with African states in terms of military aid and military equipment, and considered security from a traditional perspective, with emphasis on simultaneous pursuit of a combination of security and development. This, in essence, meant that China has moved away from predominantly sales of arms to African states to emphasis on combined pursuit of security and development. This shift seems to have taken place since 2006, 
resulting in the birth of the 'new' security concept, which, in essence, prioritizes human security over state security.

Chinese security-development nexus is derived from its domestic experience, which it wants to export to Africa. China has had 37 years of domestic experience of strengthening security and stability through economic development (Benabdallah, 2016). Whereas Mao's Cultural Revolution undermined economic growth and caused turmoil, Deng Xiaoping's reforms, driven by the 'Open Door Policy', boosted economic growth and development which improved living conditions of citizens, created jobs for the youth and reduced poverty levels as the core of the party's goals. These guaranteed internal security and peace, and made people happy. China's commitment to the development-security nexus approach can be traced back to Deng Xiaoping's vision and plan for China's industrial revolution. During that period, the Chinese Communist Party (CCP) started implementing development plans that enhanced economic growth and focused on improving living conditions for its citizens by creating job opportunities for the youth and reducing poverty levels. These measures were successful on basically three fronts: they created the economic growth the CCP had targeted; resulted in more stability and satisfaction among the people; and brought legitimacy for the CCP as it was perceived by the people to be efficient in its leadership (Chris \& Large, 2013). Thus, Deng's economic reforms and China's integration into the global economy lifted 800 million Chinese citizens out of poverty, reducing extreme poverty from $40 \%$ to less than $10 \%$, an indicator of the efficacy of China's securitydevelopment nexus (World Bank Group, 2018). President Jiang Zemin emphasized the CCP, Chinese culture, and interest of the majority of citizens as the driving forces of development to tacking all of China's problems. Likewise, Hu Jintao came up with the concept of scientific development, and $\mathrm{Xi}$ Jinping invented the China Dream, both of which place economic development as the central task of the party (Benabdallah, 2016, p. 20; Hameiri et al, 2018, p.477).

The experience with achieving security through development plans came to shape Chinese officials' conceptualization of the "new security" in the post-Cold War era, which in essence was also on a shift from understanding security as self-help to a mutual (common) international security. Mutual view of international security was mainly based on Chinese policy makers' strong belief that their methods of enhancing the legitimacy of CCP and security at home should 
also be exported abroad. Mutual security is viewed as the result of win-win cooperation on economic growth and development projects. For Chinese policy makers, regional and global security could not be achieved by an increase in arms, or by military alliances with, and selling arms to, other states. Instead, global and regional security should be achieved through three ways: mutual trust and common interest not increases in arms, military alliances, and arms race; peaceful resolution of disputes; and fostering common development (Benabdallah, 2016, p. 20).

The nexus is articulated clearly in the 2015 Africa Policy paper; and the 2015 military strategy paper that highlights mutual peaceful development, trust, and win-win as the core of security. At the Africa-China Summit of 2015, President Xi Jinping reiterated China's development-security nexus when he categorically stated that "China stands ready to take an active part in Africa's efforts in capacity building for maintaining and strengthening peace and security and support Africa in its endeavors to speed up development, eradicate poverty and realize durable peace" (Benabdallah, 2016, p. 17). Similarly, President Xi Jinping views common development, regional integration, regional economic integration, and security cooperation as the basis of building sustainable security through sustainable development. President Jinping's direct link between advancement of security, peace and resolution of conflict, on one hand, and economic development, on the other hand, is the Chinese official position. For example, the Chinese Foreign Minister, Yang Jiechi, stated succinctly: "We [Chinese policy makers] believe that development is the foundation for peace in Africa. Conflict and poverty often come hand in hand and form a vicious cycle. If Africa is to achieve durable peace and stability, it needs to speed up economic and social development and let all the people share the benefits of development" (Benabdallah, 2016, p. 19). This points to the importance of the distribution of the benefits of development. Economic growth and development, creates more jobs; reduces poverty; and guarantees internal order, security and peace. Therefore, implementing development projects are a means to conflict resolution and existence of security. China sees economic grievances as causes of conflict, which threaten security, and views peace and conflict resolution to be the result of successful economic development. This brings to the fore a security-development nexus as a framework to understand China's security practices in Africa. Thus, for Chinese foreign policy, economic development is an essential instrument for security and peace which guides the country's interactions with the world, including Africa. To China, “development is key to all problems" (Benabdallah, 2016, p. 22). This Chinese view is shared by leaders in the Global 
South, and explains why China gives priority to development, which appeals to Africa, over good governance.

\section{Security and Development Initiatives in Africa}

This section discusses the role of China in Africa's security and development. China has been engaged in a number of projects targeted at fostering security and development in Africa, in a variety of sectors. Moreover, almost all of Africa, which adheres to the one China Policy, has benefited from such projects and programmes, more especially, countries characterized by conflict, war, state fragility, and low GNP. These include the Republic of the Congo, Democratic Republic of the Congo (DRC), Sierra Leone, Somalia, South Sudan, and Zimbabwe (Benabdallah, 2016; Grieger, 2019; Tower, 2017).

In terms of security, China has been instrumental in promoting peace and security in Africa, both bilaterally and multilaterally, through peace diplomacy, UN peace efforts, and bilateral military cooperation. Its role should be appreciated given the limited capabilities of African national, subregional and regional security forces to tackle both intra- and inter-state violence. China has participated in UN peacekeeping missions through financial contributions, availing medical personnel, and soldiers as peacekeepers (Grieger, 2019). In 2017, China is said to have been the biggest contributor of peacekeepers to UN peacekeeping missions, and the second most important financial contributor of $10.29 \%$, among the UN Security Council (UNSC) members (Tower, 2017, p. 2). Etyang and Panyako (2016, p. 5) argue that 2015 data indicate that China was the topmost UNSC member contributor to the UN peacekeeping operation with a total of 3 , 084 composed of 2, 875 troops, 176 police and 33 experts. Moreover, of the 10 peacekeeping missions China participated in, 7 were in Africa, in Western Sahara, Mali, the DRC, Darfur, Liberia, South Sudan, and Cote d'Ivoire. Additionally, notable among its peace diplomacy, is its involvement in the peace process in the Sudan which culminated in the 2005 Comprehensive Peace Agreement between the government and opposition groups (Carroza, n.d; Grieger, 2019; Tower, 2017) Moreover, China has made contributions to peacebuilding or post-conflict reconstruction in Sierra Leone, Liberia, Sudan, Angola, and Democratic Republic of the Congo through the government, state-owned enterprises (SOEs), China Development Bank and private businesses. Furthermore, China has been critical to the UN-authorized anti-piracy operations off the coast of Somali in the Gulf of Aden, which has contributed to significant ending of piracy 
there (Grieger, 2019). These Chinese efforts through multilateral avenues supplement its bilateral security arrangements with individual African countries, including Djibouti where China built a military naval base in 2017. Also, the US has a military naval base in Djibouti (Grieger, 2019, p. $6)$.

China's assistance to human resource development is another contribution to peace and security in Africa. This is manifested through vocational training; government scholarships; professional training; training African farmers; building agriculture demonstration centers; intelligence sharing; joint exercises and training; and developing Africa's capacity building in peacekeeping, counter-terrorism and counter-piracy. Such trainings impart the much needed skills and knowledge to Africans that promote capacity which is not readily available in the labour market, yet critical to socio-economic development. Of direct relevance to security is China's annual training programmes to capacitate African high-ranking army officials, peacekeepers, and private security. These are important given the challenges faced by African states in maintaining law and order in the face of crimes which threaten both human and state security. Political stability guarantees much needed stability for attractive foreign investors. And, through training peacekeepers, China has capacitated and enhanced Africa's contributions to international peacekeeping missions.

China's engagement in economies of African countries has been fundamental to increased growth. China's trade with a majority of African countries and its high demand for Africa's natural resources pushed commodity prices high, culminating in the recovery of export prices and government revenues which had declined tremendously as a result of the low demand in Western markets since the mid-1970s. Also, China's investments in various productive sectors of African economies made them the fastest growing economies in the world, since 2000 (World Bank, 2015). Its investments range from mines, oil and gas, agriculture, manufacturing and service sectors (Powanga \& Giner-Reichl, 2019). 2000-2016 data show that the largest loans and grants were distributed by sector and country, respectively, as follows: Transport, 31\%, Power, 24\%, mining 15\%; and Angola 30\%, Ethiopia, 10\% and Kenya 7\% (Sun, 2019, p. 3). More important, as argued by Grieger $(2019$, p. 3), is China's investment in manufacturing targeted at African consumers and resultant generation of jobs which improve livelihoods, as well as technology transfer. Indeed, for example, Chinese investment in Ethiopia's shoe manufacturing 
has helped the country climb up the global commodity value chain (Dollar, 2016; Osei-Hwedie \& Kurantin, 2017).

Much more visible and commendable has been the emergence of China as the most important and biggest source of funds for the development of African infrastructure, both economic and social infrastructure and small- and large-scale, with direct benefits to the economy and mass of the population. Towards this end, "massive infrastructure projects, construction of government buildings and stadiums" (Tower, 2017, p. 1), and dams for electricity power generation have been undertaken throughout the continent (Du Plessis, 2016). The African Union's (AU) new headquarters in Addis Ababa, Ethiopia, is the most visible of the buildings constructed in Africa. This, in turn, has contributed to Africa's rise through improved production and competitiveness.

China has replaced the World Bank as the main source of investment in infrastructure in developing countries. Infrastructural development is critically essential to grossly infrastructuredeficient continent, be it economic or social, which hampers growth. Increasingly, infrastructure has been viewed as essential to economic growth and poverty alleviation, and create an enabling environment for the private sector to thrive and attract foreign direct investment (OECD, 2012). Therefore, China's investments in infrastructure have been widely acknowledged as necessary to Africa's continued growth. It is estimated that China financed $18.9 \%$ of infrastructure projects in Africa and has constructed 33.2\% of infrastructure projects in Africa (Grieger, 2019, p. 3). Such infrastructure is expansive and inclusive of dams, power plants, railways, roads, ports and harbours. Most prominent projects are the Tanzania Zambia Railway and the Bui Dam in Ghana. Almost all of Africa has new and wonderful airports that greet travellers on arrival. Even more significant is China's support for infrastructure that facilitates regional integration in Africa, including the Nairobi-Mombasa railway, but more especially, in relation to the recently launched African Continental Free Trade Area. Additionally, infrastructure building absorbs a lot of semiand low-skilled labour, thereby contributing to jobs creation and improving livelihoods.

The Chinese nexus is manifested through numerous avenues including the Forum for ChinaAfrica Cooperation (FOCAC), Going Out Policy, and the Belt and Road Initiative (BRI). The nexus has been prominent since the 2006 FOCAC, following the adoption of the Africa policy (Carrozza, n.d); and successive meetings of FOCAC. FOCAC is shaped largely by the framework for promoting South-South Cooperation (SSC) as an alternative to North-South 
relations. The SSC rests on the assumption that development partnership among countries of the Global South is an alternative to that of North-South as it yields mutual benefits, and encourages interaction among countries with similar developmental problems and at relatively same level of development. Therefore, it is less costly, and less exploitative (Vazquez, 2014; Centre for Policy Dialogue (CPD), 2014). The 2006 FOCAC Action Plan outlined China's commitment to work with the $\mathrm{AU}$ on peace and security, assist the $\mathrm{AU}$ in its effort to provide leadership in solving African security problems, and to participate in UN peacekeeping missions in Africa. The 2012 FOCAC augmented China's commitment to Africa's peace and security through a declaration on China-Africa Cooperative Partnership for Peace and Security, which paved the way for 2015 FOCAC commitment to financial and logistic contributions to the cash-strapped AU peace and security architecture and boosting China's participation in UN peacekeeping missions in Africa. The major recipients of the funds and logistical support are the African Standby Force (ASF); African Capacity for Immediate Response to Crises (ACIRC); and the African Union Mission in Sudan (AMIS), respectively.

The 2018 FOCAC Action Plan inaugurated the China-Africa Peace and Security Fund to strengthen cooperation on peace, security, peacekeeping, law and order and security assistance programmes, including for AU logistics. For the fight against terrorism, China, since 2018, has provided funding to the G5 Sahel Joint Force consisting of sub-regional group of countries including Burkina Faso, Chad, Mali, Mauritania and Niger; and the Multinational Joint Task Force against Boko Haram. The G5-Sahel Joint Force received US\$45 million, in 2018 (Grieger, 2019, pp. 4-6). Similarly, to underscore its importance to security cooperation with Africa, China hosted the first FOCAC China-Africa Defense and Security Forum in June 2018. The Forum allowed high ranking military officials from China, 50 out of the 55 African countries and AU officials to strategize on counter-piracy and counter-terrorism (Grieger, 2019, p. 5). The Forum was introduced at the most opportune time given the increase in terrorist attacks in Africa, including in Mali, Burkina Faso and Mozambique, where such attacks are reported frequently currently.

To operationalize the Forum's concerns, 2018 FOCAC Action Plan recommended the creation of two more Forums, namely, the China-Africa Forum on Peace and Security which held its first meeting in July 2019; and the China-Africa Forum on Law Enforcement and Security. All these 
Forums are designed to work towards enhancing intelligence sharing and the use of ICT for improving public security, counter terrorism, fight against crime, and ensuring information security Grieger, 2019). In terms of development, it is argued that the 2018 FOCAC changed China's approach towards Africa from the tradition of increasing financial pledges to commercial viability, and from resources for infrastructure to investments as the basis of development finance than development assistance to boost Africa's opportunity to development through the market as the driver (Sun, 2019).

The Going Out policy encouraged Chinese state-owned enterprises (SOEs) to go to Africa to participate in natural resource extraction, predominant sectors in African economies. Mines, energy, oil and gas are the main attractions. Another means for promoting the nexus is through the BRI which is dominant in huge infrastructure construction. Started in 2013, the BRI has been extended to Africa in a bid to push China's goals of "cross-border economic integration and improved development to promote "peaceful inter-state relations and co-operation" (Hameiri et al, 2019, p. 474). Based on the idea of Chinese peace, the BRI is supposed to realise "the objectives of mutual benefit and common security" (Hameiri et al, 2019, p. 474). The BRI demonstrates China's capability to provide global leadership.

\section{Interrogating China's security and development interests in Africa}

The emergence of China as an important security and development partner on the African continent has raised questions as to its interests or motives; and whether is an altruistic partner. Within the context of security-development nexus and relative to geo-politics, Afro-Chinese relationship may neither be the best of all worlds, as seen by Sino-optimists, nor just another era which is suspiciously similar to the past, which is dreadfully envisaged by Sino-skeptics and Sino-pessimists. Nevertheless, it is common knowledge that every Chinese initiative in the world is viewed with suspicion: Western aid to Africa is viewed as altruistic and China's is not. This might not represent the true picture. However, Scandinavian countries have been upheld as altruistic donors. This might explain China's attempts to moralize and legitimize its engagement in Africa's security and development. China accuses the West, as former colonial and neocolonial powers, for causing poverty and lack of development, which lead to conflicts, wars, violence and insecurity in Africa and the rest of the developing world (Carrozza, n.d). Moreover, China views Western capitalist development in the Global South, since the structural adjustment 
programmes and globalization, as "not a peaceful process but is inherently conflict-ridden and crisis-prone, sometimes violently ..." (Hameiri et al, 2018, p. 475), and hence, as the cause of lack of development, exploitation and oppression of Africa and the rest of the Global South. This explains why China has claimed to be the leader and voice of the Global South in international arena, including global governance structures such as the United Nations Security Council, World Trade Organization, World Bank, and the G20.

The debate between Sino-optimists and Sino-pessimists represents two polarizing viewpoints: The Sino-optimists, for example, Brautigam (2011), commends China's role in Africa as mostly beneficial in responding to Africa's economic development and infrastructural needs. Indeed, China's nexus is important to Africa because of the security and development challenges on the continent. Africa has enormous development problems which account for the label of the poorest region in the world. Although extreme poverty has declined on the continent, poverty remains most problematic at $41.3 \%$ (Begashaw, 2020, p. 10). Similarly, intra-state wars arising from subnational demands for secession or rebellion and ethnic cleavages; and political violence caused by election disputes, terrorism and lack of service delivery create enormous security challenges which rank Africa among the most unstable and insecure regions of the world. Moreover, Tower (2017) argues that the security-development nexus is an imperative because most of China's allies are conflict-ridden; and that African governments prefer China as a partner than the West because of the ease of borrowing and associated conditionalities. Thus, on the face of it, it is apparent that China's nexus seems to respond to Africa's security and development needs, which by implication, means that Africa is the beneficiary. The critics point to the contrary in their analysis of China's role in Africa's security and development that China's interests are primarily. For example, Benabdallah (2016, p. 26) questions the causal linkage between poverty and conflict as in the case of Sudan because it is difficult to prove causality.

This is the inherent problem of all mono-causal explanations as in spite of Chinese contribution to the economic performance, in terms of improved gross domestic product of South Sudan, "such economic growth did not translate into enhanced peace and security". Rather, the result has been insecurity for both Sudanese citizens due to violence between political rivals and Chinese workers at oil facilities. This resulted in reduced oil exports to China, a big loss as China is one of the biggest oil consumers in the world (Benabdallah, 2016, p. 26). This points to 
unintended consequences of the implementation of the security-development nexus initiatives. China's support for the dictatorship of Al Bashir in Sudan in international arena, including the UNSC, is also taken as an indication of safeguarding China's interests even in the face of appeals from African and Western governments (Benabdallah, 2016).

Also, the view is that the nexus is necessary for protecting China's economic interests, Chinese citizens and investments or business interests on the continent, which have increasingly fallen prey to violent attacks in host countries (Holslag, 2009; Benabdallah, 2016; Grieger, 2019). This might indicate that the nexus is not necessarily wholly for Africa's benefit, in spite of China's arguments to the contrary. Additionally, it is argued that China's engagement in Africa is directed at expanding its influence in Africa to boost its contestation for global leadership, and to promote the perception of a global power that renders assistance to other developing countries of the Global South (Grieger, 2019). Moreover, Chinese investment, in African economies and infrastructure development, is viewed as having less favourable terms than Western funding, and therefore, not beneficial to Africa (OSAA, 2015), and akin to new neo-colonialism ( $\mathrm{Su}, 2017$, 2019). Barrett (2018) views the security-development nexus, both of the past and present, as exploitative, therefore, detrimental to developing countries.

While mindful of both optimists and skeptics, this article contributes to the debate by focusing on the nature of international relations, and Africa's position on the partnership with China. Realists in international relations emphasize national interests and competition for power by states, more so, great powers. They argue that the state prioritizes and defends national interests in interactions with other states, which are the cornerstone of a state's foreign policy (Baylis, Smith \& Owens, 2014). Therefore, national interests take priority, regardless of a state's ideology and status in the international system. Indeed, to realists, survival of the state, which entails guaranteeing its security in the anarchical international system is of ultimate significance. In this respect, it is apparent that China promotes its national interests through its role in Africa's security and use of both bilateral and multilateral approaches. This reflects the win-win situation which it so vividly champions. Similarly, as an emerging power and aspirant to global leadership, its security-development nexus is a tool for boosting its influence and position as it competes for hegemonic position with the USA. Additionally, from a mercantilist point of view, which has the same assumptions as realists in international relations, states compete for wealth to 
maximize their relative power and ensure their survival and sovereignty. Wealth can be translated into military power and transform a state into hegemon (Pinctus, n.d; Goldstein \& Pevehouse, 2011). This augurs well with the changing emphasis of security-development nexus in Africa, especially, in relation to shifting approaches of FOCAC on security and development, overtime.

Questions of whose security and whose development?, can be understood by probing Africa's role, position or response to China's security-development nexus. Four issues have to be highlighted: First, is the fact that only Ian Khama, as the President of Botswana, has been the only one who publicly criticized Chinese infrastructure investments in his country. This followed problems experienced at an electricity power plant built by the Chinese. Therefore, the government blacklisted Chinese companies from government-funded construction projects (African Presidential Center, 2013; Du Plessis, 2016). This leaves the large number of leaders either silent or approving Chinese activities in Africa. In Zambia, Michael Sata based his presidential campaign bids on criticism of Chinese economic dominance and exploitation and promised to expel the Chinese once elected. He failed to fulfil his promise when he was elected President in 2011after learning that China reactivated and runs Zambia's copper mining upon which the country depends heavily (Hanauer \& Morris, 2014). However, the African population, including civil society has been vocal. Lack of criticism, even when Chinese activities run counter to the win-win and mutual benefit, arises from Africa's desire not to lose out on benefits - a typical rational calculation by African leaders.

Second, Africa's inability to negotiate and leverage its resources in order to maximize benefits from the partnership with China on security and development, is problematic. It seems Africa has not learnt from its historical relationship with former colonial powers and neo-colonial powers; and hangs on to the belief that donors are intrinsically oriented to assisting the continent. Third, Africa lacks an African policy towards China to strategize how to interact with China. This means that Africa has no united voice vis-a-vis China. However, the AU, through The Agenda 2063, aims to reorient from agenda adoption to agenda setting which might pave the way for an AU stance towards China. Lastly, Africa has yet to capitalize on China's governmentgovernment model of interaction, including FOCAC, which is relatively manageable. However, prospects look bright for one African voice in FOCAC meetings since the 2017 AU proposal to 
reduce the number of AU members attending FOCAC meetings (Grieger, 2019). Indeed, China's appointment of Chinese representative to the AU and AU representative to China point to a shift in interaction.

\section{Conclusion}

Through the security-development nexus, China's engagement with Africa has been intensified. It is apparent that Africa benefits from the assistance, especially, through peace efforts through both multilateral and bilateral channels, massive power projects and transport infrastructure, oil and mining sectors, the exports, and the skills development. However, its role has given rise to debate between optimists and pessimists on its motives as an emerging global power. However, the debate should be extended to include Africa's role in nurturing the partnership with China through negotiations and leveraging to maximize returns from security and development initiatives.

\section{References}

African Presidential Center. ( 2013). Botswana Says "No" to China, Retrieved from: http://africanpresidentialcenter.wordpress.com/2013/04/17/botswana-says-no-to-china.

Anderson, N. A. (2012), Redefining International Security: Bringing Intent Back In. Josef Korbel Journal of Advanced International Studies, (4), 27 - 47.

Baldwin, D. A. (1997). The Concept of Security. Review of International Studies. (23), 23 - 26.

Barrett, R. (2018). The Development-Security Nexus: An Exploitative Past and Present. https://www.e-ir.info/2018/07/24/the-development-security-nexus-an-exploitative-past-andpresent/.

Baylis J, Smith, S. \& Owens, P. (2014). The Globalization of World Politics. Oxford: Oxford University Press.

Begashaw, B. (2020). Strategies to deliver on the Sustainable Development Goals in Africa, in Caulibaly, B, Foresight Africa. Africa Growth Initiative at Brookings.

Benabdallah, L. (2016). China's Peace and Security Strategies in Africa: Building Capacity is Building Peace? African Studies Quarterly, vol. 16, Issues 3-4, December, pp. 1-18. Retrieved from: http://asq.africa.ufl.edu/files/v16a3.Lina_.HD_.pdf. 
Bisca, P.M. (2018). Development for security: Lending for Peace? Brookings. Retrieved from: https://www.brookings.edu/blog/future-development/2018/04/20/development-for-securitylending-for-peace/

Brautigam, D. (2011). Chinese Development Aid in Africa: What, Where, Why, and How Much? Retrieved from: https://deborahbrautigam.files.wordpress.com/2013/04/2011-brautigamchinese-aid-in-africa.pdf

Broadman, H. (2013). An Opportunity to Drive Modernization and Growth. Gridlines. Retrieved from: https://www.pwc.com/gx/en/psrc/pdf/pwc-gridlines-separating-fact-from-fiction-in-thechina-africa-relationship.pdf

Carrozza, I (n.d). China's Multilateral Diplomacy in Africa: Constructing the SecurityDevelopment Nexus, in Johanson, D, Li, J \& Wu, T, New Perspectives on China's Relations with the World. E-International Relations Publishing.

Centre for Policy Dialogue, 2014. Deconstructing South-South Cooperation: A Southern Perspective on Experience and Challenges, 1-46, April [online] Available at: www.ncaer.org/uploads/photo.../1400566352Paper-on-South-South-Cooperation.pdf

Chandler, D., (2007). The Security-development Nexus and the Rise of Anti-Foreign Policy. Journal of International Relations and Development, 10(4), 362 - 386.

Chris, A. \& Large, D. (2013). "China's Evolving Policy towards Peace and Security in Africa: Constructing a New Paradigm for Peace Building? Institute of Peace and Security Studies, 1628.

Dollar, D. (2016). China's Engagement with Africa: From Natural Resources to Human Resources. Brookings. Retrieved from: https://www.brookings.edu/research/chinas-engagementwith-africa-from-natural-resources-to-human-resources/

Du Plessis, R. (2016). China's African Infrastructure Projects: A Tool in Reshaping Global Norms. South African Institute of International Affairs Policy Insights 35, 1-14. September. Retrieved from: https://www.africaportal.org/documents/16526/saia_spi_35_du_plessis_20160930.pdf.

Etyang, O. \& Panyako, S. (2016). Chaina and Africa's Peace aand Security Agenda: The Burgeoning Appetite. Journal of African Conflicts and Peace Studies, Vo. 3, Issue 1, http://schlarcommons.usf.edu/jacaps/vol3/iss1/4.

Goldstein, J. \& Pevehouse, J. (2011). International Relations. Boston: Longman.

Grieger, G (2019). China's growing role as a security actor in Africa. Retrieved from: https://www.europarl.europa.eu/thinktank/en/document.html?reference=EPRS_BRI(2019)64223 2 
Hamaeiri, S. Jones, L. \& Zou, Y (2019). The Development-Insecurity Nexus in China's NearAbroad: Rethinking Cross-Border Economic Integration in an Era of State Transformation.

Journal of Contemporary Asia, vol. 49, No. 3, 473-499.

https://doi.org/10.1080/00472336.2018.1502802.

Hanauer, L. \& Morris, L. J. (2014). China in Africa: Implications of a Deepening Relationship. Retrieved from: https://www.rand.org/pubs/research_briefs/RB9760.html

Holslag, J. (2009). China's New Security Strategy in Africa. Summer. Retrieved from: https://www.semanticscholar.org/paper/China's-New-Security-Strategy-for-AfricaHolslag/3c2cc26b33f9a96a76e886ca7e55febb61fde755

International Peace Academy, (2004). Strengthening the Security- Development Nexus: Assessing Internal Policy and Practice since the 1990s. Retrieved from: http://www.un.org/esa/peacebuilding/Library/Strengthening_SecDev_Nexus_IPA.pdf

Johanson, V. (2014). The Security and Development Nexus: A Policy Analysis. Retrieved from: https://www.diva-portal.org/smash/get/diva2:784285/FULLTEXT01.pdf

Koponen, S. (2010). The Security-development nexus, state fragility as state building: A beginner's guide to discussion and some suggestions for orientation, in Alava, H (ed.), Exploring the Security Development Nexus: Perspectives from Nepal, Northern Uganda and Singapore. Finland: Ministry of Foreign Affairs. ISBN 978-951-724-822-8

Office of the Special Adviser on Africa (OSAA), United Nations and NEPAD. (2015). Infrastructure Development within the Context of Africa's Cooperation with New and Emerging Development Partners, 1-112 [online] Available at: www.un.org/en/africa/osaa/pdf/pubs/2015infrastructureanddev.pdf.

Organization for Economic Cooperation and Development (OECD), 2012. Mapping Support for Africa's Infrastructure Investment, 1-62 [online] Available at: www.oecd.org/daf/inv/investmentpolicy/MappingReportWeb.pdf.

Pietersee, J. N. (2000). After Post-Development. Third World Quarterly, 21(2), 175-191.

Pinctus, S. (n.d). Rethinking Mercantilism: Political Economy, the British Empire and the Atlantic World in the $17^{\text {th }}$ and $18^{\text {th }}$ Centuries. pp. 1-50.

https://warwick.ac.uk/fac/arts/ren/researchcurrent/archive/newberry/collaborativeprogramme/ren -earlymodcommunities/britishandamericanhistories/25march/session3reading/rethinkingmercantilism.pdf

Powang, L. \& Giner-Reichl, T. (2019). China's Contribution to the African Power Sector: Policy Implications for African Countries. Journal of Energy. pp. 1-11.

Stern, M. \& Ojendal, J. (2010). Mapping the Security - Development Nexus: Conflict, Complexity, Cacophony, Convergence? Security Dialogue, vol. 41, No. 1, February. Retrieved from: http://www.sagepub.co.uk/journalsPermissions.nav. 
Sumner, A \& Tribe, M. (2008). What is Development? Development Studies Theories Methods in Research and Practice. London: Sage publications.

$\mathrm{Su}, \mathrm{X}$. (2017). Why Chinese Infrastructure Loans to Africa Represent a Brand-New Type of Neocolonialism, 1-3. June 09. Available at: https://thediplomat.com/2017/06/why-chineseinfrastructural-loans-in-africa-represent-a-brand-new-type-of-neocolonialism/

Sun, Y. (2019). China's changing approach to Africa. Brookings. Retrieved from:

https://www.brookings.edu/blog/africa-in-focus/2019/02/04/chinas-changing-approach-to-africa/

Tower, J.G. (2017). Belts, Roads and Battlegrounds: Chinese Outbound Initiatives in Conflict and Post-Conflict Settings. January, pp. 1-14.

United Nations Development Program (UNDP). (1994). Human Development Report 1994. New York, Oxford: Oxford University Press.

Vazquez, K. (2014). What Future for South-South Cooperation?. Paper presented at UNDP Conference on International Development Cooperation: Trends and Emerging Opportunities. Instabul, 19-20 June. Retrieved from: https://www.academia.edu/37864884/What_Future_for_South_South_Cooperation

World Bank (2015). GDP Growth (annual \%). Retrieved from: www.data.worldbank.org/indicator/NY.GDP.MKTP.KD.ZG

World Bank Group. (2018). 40 Years of Reform and Poverty Reduction. Speech by World Bank Group President Jim Yong Kim's Remarks at the International Forum on China's Reform and Opening Up and Poverty Reduction, 1 November. Retrieved from:

https://www.worldbank.org/en/news/speech/2018/11/01/world-bank-group-president-jim-yongkim-remarks-at-the-international-forum-on-chinas-reform-and-opening-up-and-povertyreduction 